\title{
State of the Art of International Standardisation in the Field of Welding and Allied Processes
}

\author{
(O Estado da Arte da Normalização Internacional no Campo da Soldagem e dos Processos Afins)
}

\author{
Detlef von Hofel \\ ${ }^{1}$ DVS - Düsseldorf - Germany
}

\begin{abstract}
The development of new and the revision of existing ISO Standards in the field of welding and allied processes was formidable in the last five to seven years. In the middle of the year 2009 there were available more than 300 European and more than 270 International Standards in that field, most of the EN Standards are identical or very similar to ISO Standards. Industry has to take into account the new standards and the changes in the existing once especially in respect of filler materials, procedure qualification tests, personal qualification, non destructive tests and requirements to manufacturing joined products. There is a strong relation of these standards to product standards and to European Directives.
\end{abstract}

Key-words: Welding standards, quality, ISO.

Resumo: $O$ desenvolvimento de novas normas ISO e a revisão de normas ISO já existentes no campo da soldagem e de processos afins foi formidável nos últimos cinco a sete anos. Em meados de 2009 existiam disponíveis mais de 300 Normas Européias (EN) e mais de 270 Normas Internacionais nesta área, sendo a maioria das EN idênticas ou muito similares às Normas ISO. A indústria tem levando em consideração as novas normas e as alterações nas existentes, especialmente com respeito a materiais de adição, testes de qualificação de procedimento, qualificação de pessoal, ensaios não destrutivos e requerimentos para a fabricação de produtos com processos de união. Existe uma forte relação entre estas normas com normas de produtos e com as Diretrizes Européias.

Palavras-Chave: Normas de soldagem, qualidade, ISO.

\section{Introduction}

Technical standards are developed on national, regional and international levels (Figure 1). The national level does not need any interpretation, although some national standardization organizations have a strong international impact like ASME, API and AWS of the U.S. in the corresponding branches.

Examples of regional levels are:

- African Regional Organization for Standardization ( $\underline{\text { ARSO }})$

- Arab Industrial Development and Mining Organization ( $\underline{\mathrm{ARSO}})$

- European Committee for Standardization (CEN)

- Pan American Standards Commission (COPANT)

- Euro Asian Council for Standardization, Metrology and Certification (EASC)

- Pacific Area Standards Congress (PASC)

- ASEAN Consultative Committee for Standards and Quality ( $\underline{\mathrm{ACCSQ}})$

(Received in 10/02/2010; Final Text in 15/03/2010).

Based on paper published on Sudura 05/2009 (Romania). Reprinted by consent of Sudura. Note: This paper presents the status of normalization projects in the first haft of 2009
INTERNATIONAL LEVEL ISO-IEC-ITU - IIW

REGIONAL LEVEL

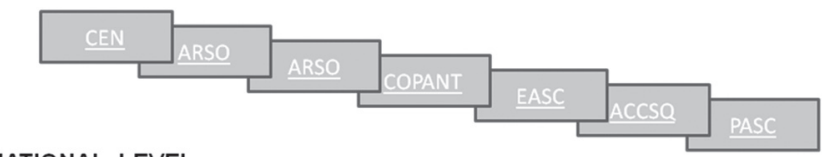

NATIONAL LEVEL

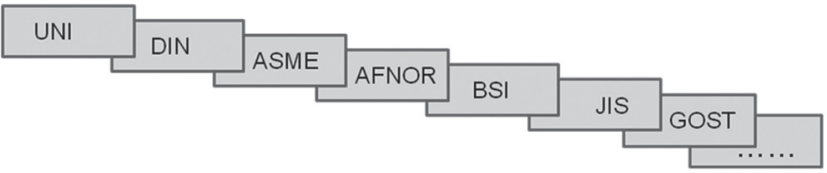

Figure 1. Levels for Standardisation Work.

European standards are developed by CEN, the European Committee for Standardisation, CENELEC, the European Committee for Electrotechnical Standardisation, both with their central offices in Brussels, and ETSI, the European Telecommunications Standards Institute with its central office in France.

This contribution mainly will deal with international standardisation activities by ISO, the International Organisation for Standardisation. ISO collaborates with its partners in international standardisation, the International Electrotechnical Commission (IEC) and the International Telecommunication 


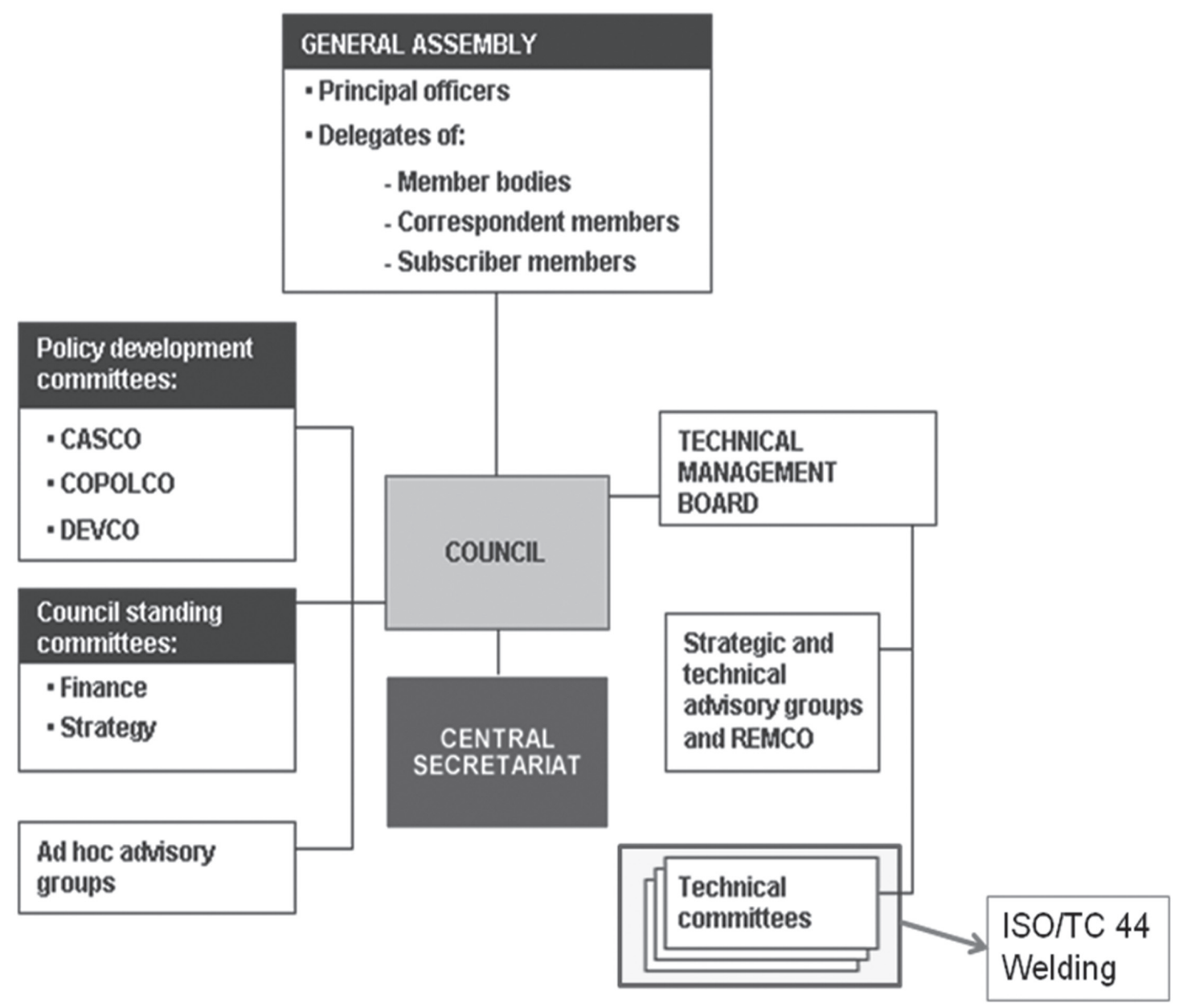

Figure 2. ISO's Structure.

Union (ITU). The three organizations, all based in Geneva, Switzerland, have formed the World Standards Cooperation (WSC) to act as a strategic focus for collaboration and the promotion of international standardization.

\section{The scope of ISO's work}

ISO has more than 17500 International Standards and other types of normative documents in its current portfolio. ISO's work programme ranges from standards for traditional activities, such as agriculture and construction, through mechanical engineering, manufacturing and distribution, to transport, medical devices, information and communication technologies, and to standards for good management practice and for services.

\section{ISO's structure}

The structure of ISO is given in Figure 2.

\section{International standardisation in the field of welding and allied processes}

The international standardization work in the field of welding and allied processes mainly is done in ISO TC 44 "Welding and allied processes". The secretariat is with AFNOR, the French national standardisation organisation, and chairman is $\mathrm{Mr}$. Lobinger, from France as well.

The scope of ISO/TC 44 reads: "Standardization of welding, by all processes, as well as allied processes; these standards include terminology, definitions and the symbolic representation of welds on drawings, apparatus and equipment for welding, raw materials (gas, parent and filler metals) welding processes and rules, methods of test and control, calculations and design of welded assemblies, welders' qualifications, as well as safety and health. Excluded: electrical safety matters related to welding which are the responsibility of IEC / TC 26"

ISO/TC 44 has published 274 ISO Standards and other ISO Documents like Corrigendum, Amendments, ISO/TR (Technical Reports) or ISO/TS (Technical Specifications). You can find the titles of these standards on the ISO Web Site by:

http://www.iso.org/iso/iso catalogue/catalogue tc/catalogue tc browse. htm? commid $=48602 \&$ includesc $=$ true $\&$ published $=$ on .

Cooperation of ISO/TC44 exists for instance with the following Technical Committees:

- TC 5 Ferrous metal pipes and metallic fittings,

- TC 10/SC 1 Technical product documentation, 
- TC 11 Boilers and pressure vessels,

- TC 26 Copper and copper alloys,

- TC 58 Gas cylinders,

- TC 79 Light metals and their alloys,

- TC 94 Personal safety -- Protective clothing and equipment,

- TC 107 Metallic and other inorganic coatings (including thermal spraying),

- TC 119 Powder metallurgy,

- TC 135 Non-destructive testing,

- TC 153/SC 1 Valves - Design, manufacture, marking and testing,

- TC 164 Mechanical testing of metals,

- TC 167/SC 1 Steel and aluminium - Structures, material and design,

- IEC TC 26 Electric welding and othe rs

The ISO Technical Committees are divided in SC's, Sub Committees, and WG's, Working Groups, if necessary.

The structure of ISO/TC44 is given in Table 1. It has participating members from 34 countries and observing members from 37 countries all over the world.

\section{Actual activities in ISO/TC44}

Standards of ISO/TC44 published in 2009 are listed in Table 2. At the present stage, ISO/TC44 and its subcommittees (SC) are working on 51 projects. These are revisions of existing standards and developments of new standards. The projects are listed in Table 3. Most of these projects are handled in a strong cooperation with CEN, the European Committee for Standardisation, following the Vienna Agreement to avoid as far as possible different standards on the same subjects on the European and the international level. Anyway there are some projects that are on European but not on international interest. These projects are listed in Table 4 and are handled only by CEN/ TC 121 "Welding and allied processes" and its sub committees. The structure of CEN/TC121 is given in Table 5. All about CEN/ TC 121 can be found under:

www.cen.eu/CENORM/Sectors/Technical Committees Workshops/ CENTechnical Committees/ CENTechnical Committees .asp? param $=6103 \&$ title $=\mathrm{CEN} \% 2 \mathrm{FTC}+121$

Table 1. Structure of ISO/TC44, Welding and allied processes.

\begin{tabular}{|l|l|}
\hline WG 1 & Underwater welding (dormant) \\
\hline WG 3 & Brazing materials and processes \\
\hline WG 4 & Welding and brazing in aerospace \\
\hline SC 3 & Welding consumables \\
\hline SC 5 & Testing and inspection of welds \\
\hline SC 6 & Resistance welding and allied mechanical joining \\
\hline SC 7 & Representation and terms \\
\hline SC 8 & Equipment for gas welding, cutting and allied processes \\
\hline SC 9 & Health and safety \\
\hline SC 10 & Unification of requirements in the field of metal welding \\
\hline SC 11 & Qualification requirements for welding and allied processes personnel \\
\hline SC 12 & Soldering materials \\
\hline
\end{tabular}

Table 2. New published Standards by ISO/TC44 in 2009.

\begin{tabular}{|l|l|}
\hline \multicolumn{1}{|c|}{ Standard } & \multicolumn{1}{c|}{ Title } \\
\hline ISO 5173:2009 & Destructive tests on welds in metallic materials -- Bend tests \\
\hline ISO 17677-1:2009 & Resistance welding -- Vocabulary -- Part 1: Spot, projection and seam welding \\
\hline ISO 5821:2009 & Resistance welding -- Spot welding electrode caps \\
\hline ISO 4063:2009 & Welding and allied processes -- Nomenclature of processes and reference numbers \\
\hline ISO 5171:2009 & Gas welding equipment -- Pressure gauges used in welding, cutting and allied processes \\
\hline ISO 2503:2009 & $\begin{array}{l}\text { Gas welding equipment -- Pressure regulators and pressure regulators with flow-metering devices } \\
\text { for gas cylinders used in welding, cutting and allied processes up to 300 bar (30 MPa) }\end{array}$ \\
\hline ISO/TR 20172:2009 & Welding -- Grouping systems for materials -- European materials \\
\hline ISO 17663:2009 & $\begin{array}{l}\text { Welding -- Quality requirements for heat treatment in connection with welding and allied } \\
\text { processes }\end{array}$ \\
\hline $\begin{array}{l}\text { ISO 15614-2:2005 } \\
\text { /Cor 2:2009 }\end{array}$ & $\begin{array}{l}\text { Specification and qualification of welding procedures for metallic materials -- Welding procedure } \\
\text { test -- Part 2: Arc welding of aluminium and its alloys }\end{array}$ \\
\hline ISO 15609-4:2009 & $\begin{array}{l}\text { Specification and qualification of welding procedures for metallic materials -- Welding procedure } \\
\text { specification -- Part 4: Laser beam welding }\end{array}$ \\
\hline
\end{tabular}


Table 3. Projects of ISO/TC44. Welding and allied processes.

\begin{tabular}{|c|c|c|c|}
\hline ISO Nr. & Title & Status* & TC/SC \\
\hline ISO/CD 544 & $\begin{array}{l}\text { Welding consumables -- Technical delivery conditions for filler } \\
\text { materials and fluxes -- Type of product, dimensions, tolerances and } \\
\text { markings }\end{array}$ & 30.99 & $\mathrm{TC} 44 / \mathrm{SC} 3$ \\
\hline ISO/CD 2553-1 & $\begin{array}{l}\text { Welding and allied processes -- Symbolic representation on } \\
\text { drawings -- Part 1: Welding }\end{array}$ & 30.60 & $\mathrm{TC} 44 / \mathrm{SC} 7$ \\
\hline ISO/FDIS 2560 & $\begin{array}{l}\text { Welding consumables -- Covered electrodes for manual metal arc } \\
\text { welding of non-alloy and fine grain steels - Classification }\end{array}$ & 50.20 & $\mathrm{TC} 44 / \mathrm{SC} 3$ \\
\hline ISO/DIS 3580.2 & $\begin{array}{l}\text { Welding consumables -- Covered electrodes for manual metal arc } \\
\text { welding of creep-resisting steels -- Classification }\end{array}$ & 40.99 & $\mathrm{TC} 44 / \mathrm{SC} 3$ \\
\hline ISO 3581:2003/CD Amd 1 & $\begin{array}{l}\text { Welding consumables -- Covered electrodes for manual metal arc } \\
\text { welding of stainless and heat-resisting steels - Classification }\end{array}$ & 30.99 & $\mathrm{TC} 44 / \mathrm{SC} 3$ \\
\hline ISO 5172:2006/CD Amd 1 & $\begin{array}{l}\text { Gas welding equipment -- Blowpipes for gas welding, heating and } \\
\text { cutting -- Specifications and tests }\end{array}$ & 30.60 & $\mathrm{TC} 44 / \mathrm{SC} 8$ \\
\hline ISO/NP 5817 & $\begin{array}{l}\text { Welding -- Fusion-welded joints in steel, nickel, titanium and their } \\
\text { alloys (beam welding excluded) -- Quality levels for imperfections }\end{array}$ & 10.99 & TC 44/SC 10 \\
\hline ISO/DIS 6947.2 & Welds -- Welding positions & 40.20 & $\mathrm{TC} 44 / \mathrm{SC} 7$ \\
\hline ISO/FDIS 7289 & $\begin{array}{l}\text { Gas welding equipment -- Quick-action couplings with shut-off } \\
\text { valves for welding, cutting and allied processes }\end{array}$ & 50.00 & $\mathrm{TC} 44 / \mathrm{SC} 8$ \\
\hline ISO/DIS 7291.2 & $\begin{array}{l}\text { Gas welding equipment -- Pressure regulators for manifold systems } \\
\text { used in welding, cutting and allied processes up to } 30 \mathrm{MPa}(300 \\
\text { bar) }\end{array}$ & 40.60 & TC $44 / \mathrm{SC} 8$ \\
\hline ISO/NP 9455-10 & $\begin{array}{l}\text { Soft soldering fluxes -- Test methods -- Part 10: Flux efficacy tests, } \\
\text { solder spread method }\end{array}$ & 10.99 & TC 44/SC 12 \\
\hline ISO/NP 9455-16 & $\begin{array}{l}\text { Soft soldering fluxes -- Test methods -- Part 16: Flux efficacy tests, } \\
\text { wetting balance method }\end{array}$ & 10.99 & TC 44/SC 12 \\
\hline ISO/FDIS 9539 & $\begin{array}{l}\text { Gas welding equipment -- Materials for equipment used in gas } \\
\text { welding, cutting and allied processes }\end{array}$ & 50.00 & $\mathrm{TC} 44 / \mathrm{SC} 8$ \\
\hline ISO/DIS 10225 & $\begin{array}{l}\text { Gas welding equipment -- Marking for equipment used for gas } \\
\text { welding, cutting and allied processes }\end{array}$ & 40.60 & $\mathrm{TC} 44 / \mathrm{SC} 8$ \\
\hline ISO/CD 10863 & $\begin{array}{l}\text { Welding -- Use of time-of-flight diffraction technique (TOFD) for } \\
\text { testing of welds }\end{array}$ & 30.99 & $\mathrm{TC} 44 / \mathrm{SC} 5$ \\
\hline ISO/CD 10882-1 & $\begin{array}{l}\text { Health and safety in welding and allied processes -- Sampling of } \\
\text { airborne particles and gases in the operator's breathing zone -- Part } \\
\text { 1: Sampling of airborne particles }\end{array}$ & 30.60 & $\mathrm{TC} 44 / \mathrm{SC} 9$ \\
\hline ISO/FDIS 11666 & $\begin{array}{l}\text { Non-destructive testing of welds -- Ultrasonic testing of welded } \\
\text { joints -- Acceptance levels }\end{array}$ & 50.00 & TC $44 / \mathrm{SC} 5$ \\
\hline ISO/DIS 11745 & $\begin{array}{l}\text { Brazing for aerospace applications -- Qualification test of brazers } \\
\text { and brazing operators -- Brazing of metallic components }\end{array}$ & 40.60 & TC 44 \\
\hline ISO/CD 12153 & $\begin{array}{l}\text { Welding consumables -- Tubular cored electrodes for gas shielded } \\
\text { and non-gas shielded metal arc welding of nickel and nickel alloys } \\
\text { - Classification }\end{array}$ & 30.99 & $\mathrm{TC} 44 / \mathrm{SC} 3$ \\
\hline ISO/NP 13585 & Brazing -- Brazer qualification & 10.99 & TC 44 \\
\hline
\end{tabular}




\begin{tabular}{|c|c|c|c|}
\hline ISO/NP 13588 & $\begin{array}{l}\text { Welding -- Use of (semi-) automated phased array technology for } \\
\text { examination of welds }\end{array}$ & 10.99 & $\mathrm{TC} 44 / \mathrm{SC} 5$ \\
\hline ISO/DIS 14171 & $\begin{array}{l}\text { Welding consumables -- Solid wire electrodes, tubular cored } \\
\text { electrodes and electrode/flux combinations for submerged arc } \\
\text { welding of non alloy and fine grain steels - Classification }\end{array}$ & 40.93 & $\mathrm{TC} 44 / \mathrm{SC} 3$ \\
\hline ISO/DIS 14174 & $\begin{array}{l}\text { Welding consumables -- Fluxes for submerged arc welding and } \\
\text { electro slag welding - Classification }\end{array}$ & 40.93 & $\mathrm{TC} 44 / \mathrm{SC} 3$ \\
\hline ISO/DIS 14341 & $\begin{array}{l}\text { Welding consumables -- Wire electrodes and deposits for gas } \\
\text { shielded metal arc welding of non alloy and fine grain steels - } \\
\text { Classification }\end{array}$ & 40.99 & $\mathrm{TC} 44 / \mathrm{SC} 3$ \\
\hline ISO/FDIS 14343 & $\begin{array}{l}\text { Welding consumables -- Wire electrodes, strip electrodes, wires } \\
\text { and rods for arc welding of stainless and heat resisting steels - } \\
\text { Classification }\end{array}$ & 50.20 & $\mathrm{TC} 44 / \mathrm{SC} 3$ \\
\hline ISO/DIS 14344.2 & Welding consumables -- Procurement of filler materials and fluxes & 40.99 & $\mathrm{TC} 44 / \mathrm{SC} 3$ \\
\hline ISO/NP 14732 & $\begin{array}{l}\text { Welding personnel -- Approval testing of welding operators for } \\
\text { fusion welding and of resistance weld setters for fully mechanized } \\
\text { and automatic welding of metallic materials }\end{array}$ & 10.99 & TC $44 / \mathrm{SC} 11$ \\
\hline ISO/FDIS 15011-1 & $\begin{array}{l}\text { Health and safety in welding and allied processes -- Laboratory } \\
\text { method for sampling fume and gases -- Part } 1 \text { : Determination of } \\
\text { fume emission rate during arc welding and collection of fume for } \\
\text { analysis }\end{array}$ & 50.20 & $\mathrm{TC} 44 / \mathrm{SC} 9$ \\
\hline ISO/FDIS 15011-2 & $\begin{array}{l}\text { Health and safety in welding and allied processes -- Laboratory } \\
\text { method for sampling fume and gases -- Part 2: Determination of the } \\
\text { emission rates of carbon monoxide (CO), carbon dioxide (CO2), } \\
\text { nitrogen monoxide (NO) and nitrogen dioxide (NO2) during arc } \\
\text { welding, cutting and gouging }\end{array}$ & 50.20 & $\mathrm{TC} 44 / \mathrm{SC} 9$ \\
\hline ISO/FDIS 15011-3 & $\begin{array}{l}\text { Health and safety in welding and allied processes -- Laboratory } \\
\text { method for sampling fume and gases -- Part 3: Determination of } \\
\text { ozone emission rate during arc welding }\end{array}$ & 50.20 & $\mathrm{TC} 44 / \mathrm{SC} 9$ \\
\hline ISO/CD 15011-5 & $\begin{array}{l}\text { 321Health and safety in welding and allied processes -- Laboratory } \\
\text { method for sampling fume and gases -- Part } 5 \text { : Identification of } \\
\text { thermal-degradation products generated when welding or cutting } \\
\text { through products composed wholly or partly of organic materials }\end{array}$ & 30.60 & $\mathrm{TC} 44 / \mathrm{SC} 9$ \\
\hline $\begin{array}{l}\text { ISO/NP } \\
\text { TS 15011-6 }\end{array}$ & $\begin{array}{l}\text { Health and safety in welding and allied processes -- Laboratory } \\
\text { method for sampling fume and gases -- Part } 6 \text { : Procedure for } \\
\text { quantitative determination of fume from resistance spot welding }\end{array}$ & 10.99 & $\mathrm{TC} 44 / \mathrm{SC} 9$ \\
\hline ISO/NP 15609-5 & $\begin{array}{l}\text { Specification and qualification of welding procedures for metallic } \\
\text { materials -- Welding procedure specification -- Part 5: Resistance } \\
\text { welding }\end{array}$ & 10.99 & TC 44/SC 6 \\
\hline ISO/NP 15614-13 & $\begin{array}{l}\text { Specification and qualification of welding procedures for metallic } \\
\text { materials -- Welding procedure test -- Part 13: Resistance butt and } \\
\text { flash welding }\end{array}$ & 10.99 & $\mathrm{TC} 44 / \mathrm{SC} 6$ \\
\hline ISO/CD 15615 & $\begin{array}{l}\text { Gas welding equipment -- Acetylene manifold systems for welding, } \\
\text { cutting and allied processes -- Safety requirements in high-pressure } \\
\text { devices }\end{array}$ & 30.60 & $\mathrm{TC} 44 / \mathrm{SC} 8$ \\
\hline ISO/DIS 17633 & $\begin{array}{l}\text { Welding consumables -- Tubular cored electrodes and rods for gas } \\
\text { shielded and non-gas shielded metal arc welding of stainless and } \\
\text { heat-resisting steels - Classification }\end{array}$ & 40.20 & $\mathrm{TC} 44 / \mathrm{SC} 3$ \\
\hline
\end{tabular}




\begin{tabular}{|c|c|c|c|}
\hline ISO/FDIS 17635 & $\begin{array}{l}\text { Non-destructive testing of welds -- General rules for metallic } \\
\text { materials }\end{array}$ & 50.00 & TC 44/SC 5 \\
\hline ISO/NP 17636-1 & $\begin{array}{l}\text { Non-destructive testing of welds -- Radiographic testing of welded } \\
\text { joints -- Part 1: X-and gamma rays techniques with film }\end{array}$ & 10.99 & TC 44/SC 5 \\
\hline ISO/NP 17636-2 & $\begin{array}{l}\text { Non-destructive testing of welds -- Radiographic testing of welded } \\
\text { joints -- Part 2: Computed testing }\end{array}$ & 10.99 & TC 44/SC 5 \\
\hline ISO/FDIS 17640 & $\begin{array}{l}\text { Non-destructive testing of welds -- Ultrasonic testing of welded } \\
\text { joints }\end{array}$ & 50.00 & TC 44/SC 5 \\
\hline ISO/NP 17653 & $\begin{array}{l}\text { Destructive tests on welds in metallic materials -- Torsion test of } \\
\text { resistance spot welds }\end{array}$ & 10.99 & TC 44/SC 6 \\
\hline ISO/NP 17654 & $\begin{array}{l}\text { Destructive tests on welds in metallic materials -- Resistance } \\
\text { welding -- Pressure test on resistance seam welds }\end{array}$ & 10.99 & $\mathrm{TC} 44 / \mathrm{SC} 6$ \\
\hline ISO/DIS 17672 & Brazing -- Filler metals & 40.99 & TC 44 \\
\hline ISO/DIS 18274 & $\begin{array}{l}\text { Welding consumables -- Wire and strip electrodes, wires and rods } \\
\text { for fusion welding of nickel and nickel alloys - Classification }\end{array}$ & 40.20 & TC 44/SC 3 \\
\hline ISO/CD 18275 & $\begin{array}{l}\text { Welding consumables -- Covered electrodes for manual metal arc } \\
\text { welding of high-strength steels -- Classification }\end{array}$ & 30.99 & TC 44/SC 3 \\
\hline ISO/FDIS 18592 & $\begin{array}{l}\text { Resistance welding -- Destructive test of welds -- Method for the } \\
\text { fatigue testing of multi-spot-welded specimens }\end{array}$ & 50.00 & TC 44/SC 6 \\
\hline ISO/PRF TR 20173 & Welding -- Grouping systems for materials -- American materials & 50.20 & $\mathrm{TC} 44 / \mathrm{SC} 10$ \\
\hline ISO/NP 22825 & $\begin{array}{l}\text { Non-destructive testing of welds -- Ultrasonic testing - Testing of } \\
\text { welds in austenitic steels and nickel-based alloys }\end{array}$ & 10.99 & TC 44/SC 5 \\
\hline ISO/FDIS 23279 & $\begin{array}{l}\text { Non-destructive testing of welds -- Ultrasonic testing -- } \\
\text { Characterization of indications in welds }\end{array}$ & 50.00 & TC 44/SC 5 \\
\hline ISO/DIS 24034 & $\begin{array}{l}\text { Welding consumables -- Solid wires and rods for fusion welding of } \\
\text { titanium and titanium alloys -- Classification }\end{array}$ & 40.20 & TC 44/SC 3 \\
\hline ISO/CD TR 28821 & $\begin{array}{l}\text { Gas welding equipment -- Hose connections for equipment for } \\
\text { welding, cutting and allied processes -- Listing of connections } \\
\text { which are either standardised or in common use }\end{array}$ & 30.99 & TC 44/SC 8 \\
\hline \multicolumn{4}{|c|}{$\begin{array}{l}\text { * Stage Codes: 00.60 Close of review, 10.20 NP ballot initiated (Secr.), } \mathbf{1 0 . 6 0} \text { Result of NP circulated (Secr.), } \mathbf{1 0 . 9 9} \text { New project } \\
\text { approved, 20.00 Project approved/registered, 20.20 WD study initiated, 20.60 Close of comment period, 20.99 WD worked out/ } \\
\text { approved by WG, 30.20 CD study/ballot initiated, 30.60 Result of CD circulated (Secr.), } \mathbf{3 0 . 9 9} \text { CD approved for registration as } \\
\text { DIS, 40.20 DIS ballot initiated (ISO/CS), } \mathbf{4 0 . 6 0} \text { Close of voting, } \mathbf{4 0 . 7 0} \text { Results dispatched, } \mathbf{5 0 . 2 0} \text { FDIS ballot initiated (ISO/CS), } \\
\mathbf{5 0 . 6 0} \text { Close of voting, Proof returned (Secr.), } \mathbf{5 0 . 7 0} \text { Circulation of Formal Vote results, } \mathbf{5 0 . 9 9} \text { Voting summary dispatched (CS), } \\
\mathbf{6 0 . 6 0} \text { Standard published (ISO/CS), } \mathbf{9 0 . 6 0} \text { Close of review, } \mathbf{9 0 . 9 2} \text { International Standard to be revised, } \mathbf{9 0 . 9 3 ~ I n t e r n a t i o n a l ~ s t a n d a r d ~} \\
\text { confirmed. }\end{array}$} \\
\hline
\end{tabular}

Table 4. Standalone EN Projects.

\begin{tabular}{|l|l|l|}
\hline \multicolumn{1}{|c|}{ CEN Standard } & \multicolumn{1}{|c|}{ Title } & Status CEN $^{*}$ \\
\hline EN 287-1:2004 & Qualification test of welders - Fusion welding - Part 1: Steels & $* *$ \\
\hline EN 910:1996 & Destructive tests on welds in metallic materials - Bend tests & 20.60 \\
\hline EN 1011-1 & $\begin{array}{l}\text { Welding - Recommendations for welding of metallic materials - Part 1: General guidance } \\
\text { for arc welding }\end{array}$ & 10.99 \\
\hline prEN 1289 rev & Non-destructive testing of welds - Penetrant testing of welds - Acceptance levels & 10.99 \\
\hline prEN 1290 rev & Non-destructive testing of welds - Magnetic particle testing & 2 \\
\hline
\end{tabular}




\begin{tabular}{|l|l|l|}
\hline prEN 1418 rev & $\begin{array}{l}\text { Welding personnel-Approval testing of welding operators for fusion welding and resistance } \\
\text { weld setters for fully mechanized and automatic welding of metallic materials }\end{array}$ & 10.99 \\
\hline prEN 1598 rev & $\begin{array}{l}\text { Health and safety in welding and allied processes - Transparent welding curtains, strips } \\
\text { and screens for arc welding processes }\end{array}$ & 10.99 \\
\hline prEN 1708-1 & Welding - Basic welded joint details in steel - Part 1: Pressurized components & 40.70 \\
\hline prEN 13133 rev & $\begin{array}{l}\text { Brazing - Braze approval } \\
\text { (prEN ISO 13585) }\end{array}$ & 10.99 \\
\hline prEN 13134 rev & Brazing - Procedure approval & 10.99 \\
\hline prEN 13507 & $\begin{array}{l}\text { Thermal spraying - Pre-treatment of surfaces of metallic parts and components for thermal } \\
\text { spraying }\end{array}$ & 40.70 \\
\hline EN 14610:2004 & $\begin{array}{l}\text { Welding and allied processes - Definitions of metal welding processes (to be replaced by } \\
\text { "reworked" ISO 857-1) }\end{array}$ & Open \\
\hline prEN 14751 & Welding - Use of time-off light diffraction technique (TOFD) for examination of welds & 10.99 \\
\hline prCEN/TR 15068 & $\begin{array}{l}\text { Gas welding equipment - Measurement of noise emitted by blowpipe for welding, cutting, } \\
\text { heating, brazing and soldering - Measurement method }\end{array}$ & 50.60 \\
\hline EN 15617 & $\begin{array}{l}\text { Non-destructive testing of welds - Time-off light diffraction technique (TOFD) - } \\
\text { Acceptance levels }\end{array}$ & 50.70 \\
\hline $\begin{array}{l}* \text { Stage Codes: 10.99 New project approved, 20.60 Close of comment period, 40.70 Results dispatched, } \\
\text { 50.60 Close of voting, Proof returned by secretariat, 50.70 Circulation of Formal Vote results } \\
* * \text { To be replaced by ISO 5173:2009 as EN ISO 5173 }\end{array}$ \\
\hline
\end{tabular}

Table 5. Structure of CEN/TC121, Welding and allied processes.

\begin{tabular}{|l|l|}
\hline CEN/TC121/SC1 & Specification and qualification of welding procedures for metallic materials \\
\hline CEN/TC121/SC1/WG8 & Welding procedure approval testing for cladding \\
\hline CEN/TC121/SC2 & Qualification requirements for welding and allied processes personnel \\
\hline CEN/TC121/SC3 & Welding consumables \\
\hline CEN/TC121/SC4 & Quality management in the field of welding \\
\hline CEN/TC121/SC4/WG1 & Welding guidelines for ferritic steels \\
\hline CEN/TC 121/SC5 & Non destructive examination \\
\hline CEN/TC121/SC5/WG1 & Radiography of welds \\
\hline CEN/TC121/SC5/WG2 & Ultrasonic testing of welds \\
\hline CEN/TC121/SC7 & Equipment for gas welding, cutting and allied processes \\
\hline CEN/TC121/SC8 & Brazing \\
\hline CEN/TC121/SC9 & Health and safety in welding and allied processes \\
\hline CEN/TC121/SC9/WG3 & Welding curtains \\
\hline CEN/TC121/SC9/WG4 & Testing and marking of equipment for air filtration for welding and allied processes \\
\hline CEN/TC121/SC9/WG5 & Fume analysis data sheets \\
\hline CEN/TC121/SC9/WG6 & Procedure for quantitative determination of fume from resistance spot welding \\
\hline CEN/TC121/WG13 & Destructive testing \\
\hline
\end{tabular}




\section{IIW and Standardisation in the field of welding}

In parallel to ISO/TC44 there does exist another organisation accepted by ISO as international standardising body in the field of welding. That is IIW, the International Institute of Welding. The mission of IIW reads as follows: "To act as the worldwide network for knowledge exchange of joining technologies to improve the global quality of life."

The IIW Main Goals are:

- To identify, create, develop and transfer the best practices for sustainable development in a sustainable environment.

- To identify, develop and implement the IIW Education, Training, Qualification \& Certification Programmes on a global basis.

- To promote the IIW and its Member Societies and services in various regions of the world for the common benefit of all.

And its Key Figures are:

- Conceived in 1947 and founded in 1948 by 13 countries, the IIW is today the largest worldwide network for welding and joining technologies.

- 53 Member Countries, representing experts in the various fields of welding and joining.

- Technical Commissions and Working Units.

- 34 Authorized National Bodies which have awarded more than 40,000 Diplomas since 1998 and 6,000 Diplomas in 2008.

Here it is not the place to explain IIW in detail, its history, its organisation etc. But it has to be mentioned that all the IIW Commissions and some other working units (Table 6) are noted to do standardisation work, but under the same rules as followed by ISO. The reason to accept another international standardisation body in the field of welding is the existing of IIW since 1948 and the availability of experts there that are not engaged in ISO.

Table 6. IIW Commissions and Select Committees that could do standardisation.

\begin{tabular}{|c|c|}
\hline IIW Working Unit & Title \\
\hline \multicolumn{2}{|l|}{ Commissions } \\
\hline C-I & Thermal cutting and allied processes \\
\hline C-II & Arc Welding and Filler Metals \\
\hline C-III & Resistance welding, solid state welding and allied joining processes \\
\hline C-IV & Power Beam Processes \\
\hline $\mathrm{C}-\mathrm{V}$ & Quality control and quality assurance of welded products \\
\hline C-VI & Terminology \\
\hline C-VIII & Health, safety and environment \\
\hline C-IX & Behaviour of metals subjected to welding \\
\hline C-X & Structural performances of welded joints - Fracture avoidance \\
\hline C-XI & Pressure vessels, boilers and pipelines \\
\hline C-XII & Arc welding processes and production systems \\
\hline C-XIII & Fatigue Behaviour of welded components and structures \\
\hline C-XIV & Education and training \\
\hline C-XV & Design, Analysis and fabrication of welded structures \\
\hline C-XVI & Polymer joining and adhesive technology \\
\hline C-XVII & Brazing Soldering and Diffusion Bonding \\
\hline \multicolumn{2}{|l|}{ Study Groups } \\
\hline SG-212 & The physics of welding \\
\hline SG-RES & Welding research strategy and collaboration \\
\hline \multicolumn{2}{|l|}{ Selected Committees } \\
\hline SC-AIR & Permanent joints in new materials and coatings for aircraft engineering \\
\hline SC-AUTO & Select Committee Automotive and Road transport \\
\hline SC-QUAL & Quality Management in welding and allied processes \\
\hline SG-SHIP & Shipbuilding \\
\hline WG-STAND & Working Group Standardization \\
\hline
\end{tabular}


IIW standardisation projects can be found on the ISO web site by:

www.iso.org/ iso/ standards development/ technical committees/ other bodies/ iso technical committee.htm? commid=55014, and clicking on "Work programme".

The Coordination of work in ISO/TC44, CEN/TC121 and IIW is done in the ISO/IIW Coordination Committee, once more to coordinate the work and to avoid duplication and competition.

Standards and Projects under CEN/TC121 and IIW lead are listed in Table 7 and 8.

Table 7. ISO/TC 44 Projects leaded by CEN/TC 121.

\begin{tabular}{|c|c|c|c|c|}
\hline EN & ISO / IIW & Title & $\begin{array}{l}\text { Status } \\
\text { CEN }\end{array}$ & $\begin{array}{l}\text { Status } \\
\text { ISO }^{*}\end{array}$ \\
\hline $\begin{array}{l}\text { prEN ISO } \\
15609-6\end{array}$ & & $\begin{array}{l}\text { Specification and approval of welding procedures for metallic materials - } \\
\text { Welding procedure specification - Part 6: Laser arc hybrid welding }\end{array}$ & 10.99 & \\
\hline $\begin{array}{l}\text { prEN ISO } \\
15011-5\end{array}$ & $\begin{array}{l}\text { ISO/CD } \\
15011-5\end{array}$ & $\begin{array}{l}\text { Health and safety in welding and allied processes - Laboratory method for } \\
\text { sampling fume and gases - Part 5: Identification of thermal-degradation } \\
\text { products generated when welding or cutting through products composed } \\
\text { wholly or partly of organic materials }\end{array}$ & 00.60 & 30.20 \\
\hline $\begin{array}{l}\text { prEN ISO } \\
15012-1 \\
\text { rev }\end{array}$ & ISO 15012-1 :2004 & $\begin{array}{l}\text { Health and safety in welding and allied processes - Requirements testing } \\
\text { and marking of equipment for air filtration - Part 1: Testing of the separation } \\
\text { efficiency for welding fume }\end{array}$ & 00.60 & 90.92 \\
\hline $\begin{array}{l}\text { prEN ISO } \\
15012-3\end{array}$ & & $\begin{array}{l}\text { Health and safety in welding and allied processes - Requirements, testing } \\
\text { and marking of equipment for air filtration - Part 3: Determination of the } \\
\text { capture efficiency of welding fume extraction devices }\end{array}$ & 00.60 & \\
\hline $\begin{array}{l}\text { prEN ISO } \\
15614-1 \\
\text { rev }\end{array}$ & ISO $15614-1: 2004$ & $\begin{array}{l}\text { Specification and qualification of welding procedures for metallic materials } \\
\text { - Welding procedure test - Part 1: Arc and gas welding of steels and arc } \\
\text { welding of nickel and nickel alloys (ISO 15614- 1:2004) }\end{array}$ & 00.60 & 90.92 \\
\hline $\begin{array}{l}\text { EN ISO } \\
15614-1 / \\
\text { prAC }\end{array}$ & $\begin{array}{l}\text { ISO } 15614-1: 2004 \text { / } \\
\text { Cor } 1: 2005 \\
\text { ISO } 15614-1: 2004 / \\
\text { Amd } 1: 2008\end{array}$ & $\begin{array}{l}\text { Specification and qualification of welding procedures for metallic materials } \\
\text { - Welding procedure test - Part 1: Arc and gas welding of steels and arc } \\
\text { welding of nickel and nickel alloys (ISO 15614-1:2004) }\end{array}$ & 10.99 & 90.92 \\
\hline $\begin{array}{l}\text { prEN ISO } \\
15653\end{array}$ & & $\begin{array}{l}\text { Metallic materials - Method of test for the determination of quasi static } \\
\text { fracture toughness of welds (ISO/DIS 15653:2006) }\end{array}$ & 40.60 & \\
\hline $\begin{array}{l}\text { prEN ISO } \\
27508\end{array}$ & & $\begin{array}{l}\text { Resistance welding - Method for the evaluation of the spot weldability of } \\
\text { coated and uncoated weld bonded sheet materials }\end{array}$ & 10.99 & \\
\hline
\end{tabular}

Table 8. IIW Standards and IIW Standardisation Projects.

\begin{tabular}{|l|l|l|l|}
\hline \multicolumn{1}{|c|}{ ISO Standard Nr. } & IIW Com-mission & \multicolumn{1}{|c|}{ Title } & \multicolumn{1}{c|}{ Status * } \\
\hline ISO 3580: 2004 & II & $\begin{array}{l}\text { Welding consumables -- Covered electrodes for manual metal arc } \\
\text { welding of creep-resisting steels - Classification }\end{array}$ & 90.92 \\
\hline ISO/DIS 3581 & II & $\begin{array}{l}\text { Welding consumables - Covered electrodes for manual metal arc } \\
\text { welding of stainless and heat resisting steels - Classification }\end{array}$ & IIW \\
\hline ISO/DIS 3690 & II & $\begin{array}{l}\text { Welding and allied processes -- Determination of hydrogen content } \\
\text { in arc weld metal }\end{array}$ & 40.20 \\
\hline ISO 6847: 2000 & II & $\begin{array}{l}\text { Welding consumables -Deposition of a weld metal pad for } \\
\text { chemical analysis }\end{array}$ & $90.93-2006$ \\
\hline
\end{tabular}




\begin{tabular}{|c|c|c|c|}
\hline ISO 8249: 2000 & II & $\begin{array}{l}\text { Welding - Determination of Ferrite Number (FN) in austenitic and } \\
\text { duplex ferritic-austenitic Cr-Ni stainless steel weld metals }\end{array}$ & $90.93-2006$ \\
\hline ISO/PRF TR 13393 & II & $\begin{array}{l}\text { Welding consumables - Hard facing classification - } \\
\text { Microstructures }\end{array}$ & 60.60 \\
\hline $\begin{array}{l}\text { ISO 14343: } 2002+ \\
\text { Amd.2006 }\end{array}$ & II & $\begin{array}{l}\text { Welding consumables -- Wire electrodes, strip electrodes, wires } \\
\text { and rods for fusion welding of stainless and heat resisting steels } \\
\text {-- Classification }\end{array}$ & 90.92 \\
\hline ISO 14344: 2002 & II & $\begin{array}{l}\text { Welding and allied processes -- Flux and gas shielded electrical } \\
\text { welding processes -- Procurement guidelines for consumables }\end{array}$ & 90.92 \\
\hline ISO 14372: 2000 & II & $\begin{array}{l}\text { Welding consumables - Determination of moisture resistance of } \\
\text { manual metal arc welding electrodes by measurement of diffusible } \\
\text { hydrogen }\end{array}$ & $30.99-2009$ \\
\hline ISO 10447. 2006 & III & $\begin{array}{l}\text { Resistance welding -- Peel and chisel testing of resistance spot and } \\
\text { projection welds }\end{array}$ & 90.20 \\
\hline ISO 14270: 2000 & III & $\begin{array}{l}\text { Specimen dimensions and procedure for mechanized peel testing } \\
\text { resistance spot, seam and embossed projection welds }\end{array}$ & $90.93-2005$ \\
\hline ISO/DIS 14271 & III & $\begin{array}{l}\text { Resistance welding -- Vickers hardness testing (low-force and } \\
\text { micro hardness) of resistance spot, projection, and seam welds }\end{array}$ & 40.20 \\
\hline ISO 14272: 2000 & III & $\begin{array}{l}\text { Specimen dimensions and procedure for cross tension testing } \\
\text { resistance spot and embossed projection welds }\end{array}$ & 90.93 \\
\hline ISO 14273: 2000 & III & $\begin{array}{l}\text { Specimen dimensions and procedure for shear testing resistance } \\
\text { spot, seam and embossed projection welds }\end{array}$ & $90.93-2005$ \\
\hline ISO 14323: 2006 & III & $\begin{array}{l}\text { Specimen dimensions and procedure for impact shear and cross } \\
\text { tension }\end{array}$ & $60.60-2006$ \\
\hline ISO 14324: 2003 & III & $\begin{array}{l}\text { Resistance spot welding - Destructive tests of welds - Method for } \\
\text { the fatigue testing of spot welded joints }\end{array}$ & $90.60-2008$ \\
\hline ISO 14329: 2003 & III & $\begin{array}{l}\text { Resistance welding - Destructive tests of welds - failure types and } \\
\text { geometric measurements for resistance spot, seam and projection } \\
\text { welds }\end{array}$ & $90.60-2008$ \\
\hline ISO 14373: 2006 & III & $\begin{array}{l}\text { Procedure for spot welding on uncoated and coated low carbon } \\
\text { and high strength steels }\end{array}$ & $60.60-2006$ \\
\hline ISO 16432: 2006 & III & $\begin{array}{l}\text { Procedure for projection welding of coated and uncoated low } \\
\text { carbon steels }\end{array}$ & $60.60-2006$ \\
\hline ISO 16433: 2006 & III & $\begin{array}{l}\text { Procedure for resistance seam welding of coated and uncoated low } \\
\text { carbon steels }\end{array}$ & $60.60-2006$ \\
\hline ISO/DIS $25239-1$ to 5 & III & $\begin{array}{l}\text { Friction stir welding - Aluminium (Vocabulary, Design, Operators, } \\
\text { WPQ, Quality and Inspection) }\end{array}$ & $\begin{array}{l}\text { CEN/TC121 } \\
40.20\end{array}$ \\
\hline ISO/DIS 11699-1 & $\mathrm{V}$ & Classification of X-ray film system for industrial radiography & Approved \\
\hline ISO/DIS 11699-2 & $\mathrm{V}$ & $\begin{array}{l}\text { Industrial radiographic film - Control of film processing by means } \\
\text { of reference values }\end{array}$ & Approved \\
\hline ISO/AWI 22823 & $\mathrm{~V}$ & Classification of defects in metallic fusion welds & 20.00 \\
\hline ISO $24497-1$ to $3: 2007$ & $\mathrm{~V}$ & $\begin{array}{l}\text { Non-destruction testing - Method of metal magnetic (Vocabulary, } \\
\text { Requirements, Inspection) }\end{array}$ & $60.60-2007$ \\
\hline--- & $\mathrm{V}$ & $\begin{array}{l}\text { Technical evaluation of black light equipment for manual } \\
\text { application }\end{array}$ & $\begin{array}{l}\text { Work in } \\
\text { progress }\end{array}$ \\
\hline--- & $\mathrm{V}$ & $\begin{array}{l}\text { General principles of radioscopic inspection of construction } \\
\text { materials by X- and gamma rays. (a) Equipment. (b) Specific } \\
\text { applications - welds, light alloy castings }\end{array}$ & $\begin{array}{l}\text { Work in } \\
\text { progress }\end{array}$ \\
\hline
\end{tabular}




\begin{tabular}{|c|c|c|c|}
\hline ISO/NP TR 13392 & IIIV & $\begin{array}{l}\text { Health and safety in welding - Arc welding fume components } \\
\text { related to welding processes and consumable type }\end{array}$ & 10.99 \\
\hline--- & IIIV & Health and safety aspects of welding - Health and safety checklist & $10.99-2009$ \\
\hline --- & IIIV & $\begin{array}{l}\text { Health and safety aspects of welding - Non-consumable thoriated } \\
\text { tungsten electrodes }\end{array}$ & $30.00-2009$ \\
\hline ISO/TR 22824: 2003 & IX & $\begin{array}{l}\text { Welding consumables - Predicted and measured FN in } \\
\text { specifications - A position statement of the experts of IIW } \\
\text { Commission IX }\end{array}$ & $60.60-2003$ \\
\hline ISO/TR --- & IX & Comparison of preheat predictive methods & $10.00-2009$ \\
\hline ISO/TR --- & IX & $\begin{array}{l}\text { Test procedure for creep crack initiation and growth testing of } \\
\text { metallic materials }\end{array}$ & 30.99-2009 \\
\hline ISO/PRF TR 14345 & XIII & Recommendations on the fatigue testing of welded components. & $30.99-2009$ \\
\hline ISO 14347: 2008 & XIII & $\begin{array}{l}\text { Fatigue -- Design procedure for welded hollow-section joints -- } \\
\text { Recommendations }\end{array}$ & 60.60 \\
\hline ISO/WD 14731 & XIV & $\begin{array}{l}\text { A recommended practice for the approval of personnel employed } \\
\text { in the supervision of welding }\end{array}$ & WD stage \\
\hline
\end{tabular}

\section{European Market}

In the European Union the harmonisation of the European Market is done mainly by European Directives.

EC directives define the "essential requirements", e.g., protection of health and safety that goods must meet when they are placed on the market.

The European standards bodies have the task of drawing up the corresponding technical specifications meeting the essential requirements of the directives, compliance with which will provide a presumption of conformity with the essential requirements. Such specifications are referred to as "harmonised standards".

Some of these harmonised standards have a strong relation to welding, see Table 9. In the case these product standards are the basis for contracts for manufacturers it is eminently important to consider the standards of CEN/TC 121 and/or ISO/TC 44.

Table 9. European Standards with relation to European Directives.

\begin{tabular}{|l|l|l|}
\hline European Directive Nr. & Title & Short Cut \\
\hline 87/404/EEC & Simple Pressure Vessel Directive EN 286 & SPVD \\
\hline 97/23/EC & Pressure Equipment Directive EN 13445 & PED \\
\hline 99/36/EC & Transportable Pressure Equipment Directive div. & TPED \\
\hline 89/106/EEC & Construction Product Directive EN 1090 & CPD \\
\hline 01/16/EC & Conventional Rail System Directive EN 15085 & CRSD \\
\hline 96/48/EC & High Speed Rail Directive EN 15085 & HSRD \\
\hline $\begin{array}{l}\text { 98/37/EC } \\
\text { 2006/42/EC }\end{array}$ & Machinery Directive div. & \\
\hline
\end{tabular}

